Chapter 2

\title{
Transnational Memories and the Practices of Global Justice in the Ayotzinapa Case
}

\author{
Silvana Mandolessi
}

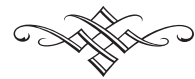

The question of transnational memory is indissolubly linked with the emergence and consolidation of globalization, a process that has undermined and reconfigured the importance of the nation as a locus of meaning. Although a variety of competing - and sometimes contradictory - ways in which to define "globalization" exist, there is agreement on the increase and influence of transnational phenomena in the last four decades. Transnationalism "refers variously to forces, processes, institutions and structures which, by going across, above, below and through hitherto relatively stable national borders, render the latter ever more porous and flexible in complex ways" (Inglis 2016: 143). This proliferation of transnational phenomena as a defining feature of globalization had a profound impact on memory studies. If hitherto the research on the formation of collective memory had been centered on the nation as the privileged territory of inquiry and the realm in which collective memory was defined and contested, the necessity to transcend theses boundaries in order to interrogate memory as a "transnational formation" soon became evident (Erll 2011; De Cesari and Rigney 2014; Assmann and Conrad 2010; Assmann 2014; Bond and Rapson 2014; Sierp and Wüstenberg 2015).

Nevertheless, in spite of the multifarious studies on transnational memory, the role of agency and the social and political effects of transnational memory work have remained undertheorized. Much attention has been devoted to 
how memory travels and is appropriated in different contexts far from the original one, and how memory becomes hybrid, "multidirectional" (Rothberg), "globital" (Reading), "travelling" (Erll), "cosmopolitan" (Levy and Sznaider), or "unbound" (Bond et al.), but the effects or the outcomes of these movements has aroused less interest in the literature.

As Sierp and Wüstenberg point out in the introduction, "despite the fact that memory research talks a great deal about actors, ... very little has been done to systematically consider the role of agency in the making, reproduction, and transformation of memory" (emphasis in original). Since agency implies the power to create change, focusing on agency is essential to understand the extent to which transnational memory work contributes to fight against structural and situational forms of violence, advocating for the respect of human rights in places where these are violated.

In this chapter, I analyze transnational memory following the four elements outlined in the introduction-actors, structures, practices, and outcomes - in the case of the disappearances of forty-three students from Ayotzinapa, Mexico, in 2014. First, I discuss why the issue of agency and the outcomes of transnational memory represents a "hard" aspect for theorization. Then, drawing on the work of Kurasawa (2007), I propose to approach transnational memory as a crucial component of the project of global justice. Kurasawa stresses the importance of conceiving of human rights not as ontological attributes that we enjoy as members of humankind but as a set of practices, "capacities that groups and persons produce, activate and must exercise by pursuing ethico-political labor." After sketching the sociopolitical context of the Mexican "War on Drugs," I analyze the transnational memory work in this case in three different initiatives: the work of the Interdisciplinary Group of Independent Experts (GIEI for its Spanish initials), the Forensic Architecture online platform "The Ayotzinapa Case: A Cartography of Violence," and the initiative Ayotzinapa: Visual Action. Read together, these actions cover a spectrum of actors-intergovernmental organizations, research centers, activists, and artists, as well as different dimensions: legal, forensic, aesthetic. Finally, I discuss the potential of "structurally transformative agency" (Hays 1994: 64) to disrupt the structure of impunity that has prevailed in Mexico.

The lack of attention devoted to agency in the study of transnational memory may due to the convergence of different factors. The issue of agency and the outcomes of transnational memory can be seen as representing either a "hard" aspect for theorization or a shortcoming of certain perspectives adopted to approach this discursive formation.

First and at the most profound level, the temporality of memory is discontinuous. A traumatic event that was not perceived as significant at the time when it happened can remain latent and gain relevance many years or decades after it took place. In this sense, the work of memory carried out by organi- 
zations or individuals around this event might appear as having no impact and, thus, no outcomes in the public sphere. When, in a different political or historical situation the event becomes an object of collective memory, it is revealed that the previously unnoticed work followed a kind of subterranean trajectory, producing effects at a time distant from the original one in which it was performed. In order to assess the effects, therefore, it is necessary to pay attention to long-term developments, which involves expanding the temporal horizons of memory studies, something that Erll and Rigney in a recent special issue on "Cultural Memory Studies after the Transnational Turn" identify as a necessary step to take discussions forward (Erll and Rigney 2018: 272).

Second, many of the studies on transnational memory have focused on "cultural memory," the flagship concept for scholars approaching the study of memory from various disciplines in the humanities (literary studies, media studies, cultural studies, cultural history), for whom the primary focus of research is culture rather than the actors and institutions involved in its formation (who take center stage in social science research, whose main concept is "collective memory") (Rigney 2016). Here the interest lies in media, forms, symbols, and contents more than in the carriers of memory, which is reflected in how the circulation of memory is often described - movement appears as incessant, continuous, unintentional, restless, without beginning and without end. Erll, for example, defines "travelling memory" as the "incessant wandering of carriers, media, contents, forms, and practices of memory, their continual 'travels' and ongoing transformations through time and space, across social, linguistic and political borders" (2011: 11, emphasis added).

Third, digital media play a crucial role in the transnationalization of memory (Garde-Hansen et al. 2009; Assmann and Conrad 2010; Neiger et al. 2011; Hoskins 2018; Groes 2016). Digital media has a pervasive capacity to connect, distribute, and put objects in motion, giving room to an unprecedented volume of flows. The hyperconnectivity that characterizes digital culture posits a constituting agency that is both technological and human, that is, a different type of agency that, according to Hoskins, is so pervasive that it implies the end of "collective memory" and the emergence of the "memory of the multitude" (Hoskins 2018: 92).

Fourth, even if we focus on the literature from the perspective of social sciences, where authors are more interested in the work performed by concrete actors, the agency and the possibility of assessing the outcomes of these actions still seems difficult. In their pioneering work Activists beyond Borders (1998), Keck and Sikkink posit the "boomerang pattern" as a model to explain how transnational advocacy networks influence domestic scenarios. If, for whatever reason, individuals (or organizations) in a country are unable to effectively persuade their government to initiate change, they may nonetheless be able to activate a transnational network focused on the issue. This 
network can in turn influence other states and international organizations that can then exert pressure on the original state at the global level. As the boomerang pattern model demonstrates, agency is not linear or the property of a single actor but rather results from a combination of diverse "agencies" that interact in complex and recursive ways. Understood in this way, the "boomerang pattern," which has proved to be essential to describe the way in which transnational advocacy networks work, highlights the inherent complexity and the multiplicity of agents and dimensions involved in the analysis. Hence, I argue that the scholarship on transnational advocacy networks and the constitution of a global civil society is the most fruitful framework to analyze agency and outcomes of transnational memory.

\section{Global Civil Society and the Work of Global Justice}

In the book The Work of Global Justice (2007), Fuyuki Kurasawa proposes a critical theory of global justice. According to Kurasawa, the project of global justice stands as shorthand for numerous and diverse struggles around the planet aiming to fully and universally realize socioeconomic and civilpolitical rights via an alternative globalization (2007: 2). These struggles are enacted "from below" by what has been called the "global civil society," a constellation of nonstate actors including multiple forms of associations such as nongovernmental organizations, international networks, social movements, campaigns, and activists. Relying on the discourse of human rights, agents in global civil society fight against structural and situational forms of violence, advocating for the respect of human rights in places where these are violated. It is important to highlight that human rights are here conceived of not as-or not only as-ontological attributes that we enjoy as members of humankind or entitlements that are legislated on our behalf by states or international organizations but as a set of practices, or, as Kurasawa puts it, "capacities that groups and persons produce, activate and must exercise by pursuing ethico-political labor” (2007: 14). The argument made by Kurasawa relies entirely on the notion of work, that is, on the concrete actions performed by groups and individuals in order to transform the "abstract" discourse of human rights into a set of emancipatory possibilities. As Kurasawa puts it,

Whether or not these possibilities become actualized depends less on formal normative principles and institutional arrangements than on the work of global justice, that is, how and to what extent civic associations enact the social labour required to counter the sources of structural and situational violence around the planet. (2007: 2) 
Without this ethico-political labor, human rights are at risk of remaining merely as a well-meaning but ineffective discourse.

What then is the relationship between transnational activism and memory? Memory is the first terrain in which this labor is performed. Based on the human rights discourse, activist groups "push for greater public debate about the past (how do we remember crimes against humanity, and how do we deal with their contemporary effects?), the present (how should we halt collective suffering in our midst, and how do we achieve a just world order?) and the future (how do we avert eventual humanitarian disasters, and how do we promote the capacities of all?), including challenging systemic sources of inequality and domination" (Kurasawa 2007: 3). In this sense, we can affirm that in pursuing the work of global justice, transnational groups and individuals simultaneously perform memory work. Memory originates here because human rights violations that are not recognized as such do not give rise to collective memory. Moreover, in human rights activism, memories from other latitudes are mobilized to make sense of a case, memories not only in terms of content or forms but also of practices and procedures, memories of "knowledge." Paraphrasing Michael Edwards (2011), seen in this way, memory is simultaneously a goal to aim for, a means of achieving it, and a framework for engaging with each other about ends and means. The practices of global justice become (transnational) memory practices that give way to hybrid, local, and cosmopolitan formations of memory. In fact, the five modes of practice of global justice posited by Kurasawa-bearing witness, forgiveness, foresight, aid, and solidarity - are also memory practices. Each of them, although perhaps "aid" to a lesser extent, are regular components of what we conceive of as the work of memory, a work that relates past human rights violations, present suffering, and the possibility of a better future in an inextricable way.

What place does the issue of agency and the assessment of outcomes occupy in this view? Kurasawa states at a general level that the importance attached to work and practice in his theory counteracts a deterministic view of globalization, a view that presupposes that forces and fluxes work independently from human agents. "Practice" is understood as both "structuring and structured," which means that actors engaging in a mode of practice have the capacity to contribute to the creation, reproduction, and transformation of established relations and institutional fields of power within which it is located (2007: 11-12). Acting together, groups and individuals can obtain results, even if these results are "rather modest" (2007: 15) when we consider the state of the world today. The word "struggle," in fact, points to the "Sisyphean character" of the work of global justice, which essentially consists of perpetually difficult, even flawed and aporetic labor.

The question about the "success" of human rights has provoked vigorous debate among scholars in recent years (De Greiff and Cronin 2002; Bleiker 
2004; Chandler 2004; Jordan 2011). The recent book Evidence for Hope (2017) by Kathryn Sikkink opens with this question: "Do human rights work? That is, have human rights law, institutions and activism produced positive change in the world?" (Sikkink 2017: 3). Sikkink makes the case that yes, human rights work. In the same vein as Kurasawa, who stresses that there is "no moment of transcendence, finality of perfection" but rather a contingent and constant struggle (Kurasawa 2007: 15), Sikkink contends that change comes slowly, but in the long term, human rights movements have been largely effective. The relevance of this question for memory is rather obvious: given the intrinsic link between human rights and memory-memory has been understood since the inception as a memory of atrocious past - to predict the failure of human rights would imply to decree the failure of memory, its incapacity to function as prevention of future atrocities. What is at stake when we formulate questions about the outcomes of memory is no less than one of the premises underpinning the belief in the function of memory work, that is, the "never again" mandate, according to which remembering the atrocities of the past is a crucial condition for preventing their repetition.

In what follows, I draw upon this literature to analyze a recent case of a human rights violation in Mexico, the September 2014 disappearance of forty-three students from Ayotzinapa, which had global resonance. After briefly sketching the context - of Latin America as a region, and Mexico in particular-I examine three transnational initiatives created around the case of Ayotzinapa. I conclude by suggesting how to conceive of the outcomes of transnational memory in this case, when observed against the background of the "undeniable atrocities" that have taken—and are taking-place in the context of the War on Drugs.

\section{The Context}

Although Latin America has a long history of structural and situational violence, it is the period of the 1970s and 1980s that has become the privileged object of the construction of memory in the continent. During these decades, many countries underwent serious human rights violations in the context of dictatorships or authoritarian regimes. In the Southern Cone, a series of diverse military coups overthrew elected governments: military forces took power in Chile and Uruguay in 1973 and in Argentina in 1976, while Brazil and Paraguay had begun their long dictatorial experiences several years before, in 1954 and 1964 respectively. The repression was coordinated at the regional level, under what was called "Plan Condor," resulting in thousands of deaths, political prisoners, exiles, and disappeared persons. 
It was the human rights movement that became the pivotal force behind inscribing dictatorial repression as a "violation of human rights." This required a change of paradigm: before, domination and social and political struggles were interpreted in terms of class struggles or national revolutions. With the advent of the human rights movement, memory policies were framed in human rights terms.

Interesting to note is that it was not political parties who led this paradigmatic change but a wide network that included relatives of victims, members of religious communities, activists, and intellectuals-new social movements that until then had not had leadership or a visible presence in the public sphere. Women, for example, became key players, particularly in Argentina with groups that would become emblematic, such as the Mothers and Grandmothers of Plaza de Mayo (Jelin 2017: 49-50).

Together with domestic human rights networks, supporting their struggles and amplifying their demands, transnational actors played a crucial role during the period. Focusing on Argentina, which can be considered the paradigmatic case of the Southern Cone, Keck and Sikkink attribute this success to the working together of domestic and transnational networks. In Activists beyond Borders (1998), they show how the human rights movement in Argentina was supported by a transnational advocacy network:

The value of the network perspective in the Argentine case is in highlighting the fact that international pressures did not work independently, but rather in coordination with national actors. Rapid change occurred because strong domestic human rights organizations documented abuses and protested against repression, and international pressures helped protect domestic monitors and open spaces for their protest. International groups amplified both information and symbolic politics of domestic groups and projected them onto an international stage, from which they echoed back into Argentina. This classic boomerang process was executed nowhere more skilfully than in Argentina. (Keck and Sikkink 1998: 118)

While Argentina appears as "the" example of effective work of transnational advocacy networks, Keck and Sikkink consider Mexico as the "counterexample" of these struggles. In the same period, Mexico failed to attract the attention of the international community to the massacre of the students in Tlatelolco Square in 1968.

In fact, Mexico is frequently considered an atypical case within Latin America. While the Southern Cone countries endured very repressive military dictatorships during the 1970s and 1980s, Mexico maintained a long-established civil government, the political structure of which did not change substantially until the 1990s. While the South American dictatorships adopted a 
language on the extreme right that radicalized the anticommunist discourse of the Cold War, the Mexican government adopted slogans emanating from the Revolution at the beginning of the century and attacked the human-rightsviolating practices of dictatorships in human rights forums, while also providing asylum to many politically persecuted individuals from South America (Dutrénit Bielous and Varela Petito 2010: 11-12). However, during the same period, the Mexican state carried out a policy of repression against political activists and social leaders during the so-called "Dirty War." As a result of this policy, there are currently more than six hundred cases of persons who disappeared at the hands of the Mexican government during that period and which have been registered by state agencies such as the National Human Rights Commission (CNDH). Unofficial figures estimate the number of disappeared persons between six and twelve hundred, yet official responsibility has not been recognized in all of these cases.

Although relatives have requested clarification regarding the whereabouts of the disappeared and demanded justice since the 1970s, their struggle against impunity remains largely invisible. As Sylvia Karl states,

The Mexican Dirty War is a somewhat forgotten event, both in Mexican and international conflict recollection ... In thinking of political violence and Dirty Wars in Latin America, Mexico is not often the first country to come to mind. (Karl 2014: 2)

The disappearances that took place in the framework of the Dirty War of the 1970s and 1980s belong to a first wave of disappearances. Since 2006, with the beginning of the War on Drugs, a new and complex scenario emerged in Mexico, characterized by an essential ambivalence: while, on the one hand, violence has increased in the last decade in an inconceivable way, the framework in which violence is exercised poses a problem to frame it as violations of human rights. Since the beginning of the "war," nearly two hundred thousand people have been killed and more than sixty thousand have disappeared. But the violations of human rights-particularly of physical integrity rights, such as arbitrary detentions, torture, executions, and disappearances-were not seen as "real" violations of human rights norms capable of stirring international attention. According to Anaya Muñoz (2013) Mexico represents a "hard case" for the globalization of human rights law, for two main reasons: first, a large proportion of victims of violence were presumed to be actively involved in criminal activities, and thus they could not easily be presented as innocent or vulnerable individuals worthy of solidarity and protection from international actors. Second, the human rights regime is based on the enduring principle of state responsibility. In this case the direct perpetrators are presumed to be nonstate actors, namely, criminal organizations. Alleged involvement of the victims in criminal activities and lack of evidence for 
direct involvement of the state as perpetrator were the main causes preventing the effective framing of deaths in Mexico as violations of human rights.

\section{The Ayotzinapa Case: Global Civil Society and the Work of Global Justice}

On the night of 26 September 2014 and into the early hours of 27 September, students from the Escuela Normal Rural de Ayotzinapa were attacked by local police acting in collusion with criminal organizations in the town of Iguala, Guerrero. Numerous other branches of the Mexican security apparatus were also involved in the assault, including state and federal police forces and the military. Six people were murdered — including three students-forty wounded, and forty-three students forcibly disappeared. In an attempt to close the case, the Mexican state constructed a fraudulent narrative-verdad histórica (historical truth)—according to which the students were assassinated by the cartel Guerreros Unidos and then incinerated in the Cocula landfill. The whereabouts of the students remain unknown, and their status as disappeared continues to this day.

The mass disappearance brought about the biggest political crisis in Mexico in the last decade. In contrast to other cases that have taken place during the War on Drugs, this case also resonated particularly strongly in the global arena. During the months following the disappearance of the forty-three students, transnational actors became actively involved in different practices of denouncing the crime and demanding justice.

Global civil society became involved in the Ayotzinapa case in three ways that can be described as follows: forms of association life, such as international nongovernmental associations (INGOs), social movements, and human rights organizations, organized campaigns to denounce the violation and demand justice; these agents based their collective work on the norms of a good society, defined by values such as cooperation, nonviolence, and respect for human rights; finally, these struggles, taken together, formed a global arena for public deliberation (Jordan 2011: 94).

Among the many actions performed as modes of practice of the work of global justice in the Ayotzinapa case, I will explore three: the work of the Interdisciplinary Group of Independent Experts (GIEI), the Forensic Architecture online platform "The Ayotzinapa Case: A Cartography of Violence," and the initiative Ayotzinapa: Visual Action. Read together, these actions cover a spectrum of actors-intergovernmental organizations, research centers, activists and artists, as well as different dimensions: legal, forensic, aesthetic. All of them enact the work of global justice through the practice of bearing witness and solidarity (Kurasawa 2007). 


\section{The Inter-American Commission on Human Rights and the Work of the GIEI}

The Mexican government initiated an investigation of the case shortly after the disappearance of the students. However, this investigation was questioned from the beginning, marked by inconsistencies, irregularities, and the suspicion that the government wanted to quickly "close" the case by shifting blame to local forces and organized crime and thus obliterating the federal government's responsibility in what happened. Faced with this situation, the Inter-American Commission on Human Rights, an intergovernmental body that plays a central role in Latin America, in agreement with representatives of the victims and the Mexican state, intervened and formed an independent expert group to investigate the case.

The GIEI (Grupo Interdisciplinario de Expertos Independientes) was made up of five specialists from different Latin American and European countries who carried out an independent investigation in two stages between 2015 and 2016 on the forced disappearance of the students. Drawing on the sources and data provided by the government and their own research, the GIEI produced two reports. Although this investigation could not discover the ultimate truth of the facts since the whereabouts of the students remain unknown to this day, the work of the GIEI was fundamental to deny the version that was-and continues to be-sustained by the Mexican government. According to the verdad historica, the police handed the students over to members of Guerreros Unidos, who took them to a rubbish dump outside of the town of Cocula where they killed them and burned the bodies on a pyre. Their remains were then collected in plastic bags and dumped into a river. On the contrary, the GIEI showed that the alleged incineration of the students was scientifically impossible. Moreover, in its reports, the GIEI contextualizes the violence historically, highlights the necessary measures that have to be taken to assist the relatives of the victims - who are victims themselves because the crime of enforced disappearance implies psychological wounds sustained from the uncertainty and the impossibility to mourn-and makes recommendations to the Mexican government regarding the investigation of human rights violations in the country. By contesting the "historical truth," the name that the government itself uses for its version of what happened, the GIEI shows that Ayotzinapa was not an isolated case. On the contrary, the reports describe how the government tried to cover up information and evidence, thereby placing the case into a wider context of state-sponsored violence. Far from being a singular case or an exception that can be reduced to the local level, the reports show the extent of corruption and involvement of all levels of the state. 
"This report provides an utterly damning indictment of Mexico's handling of the worst human rights atrocity in recent memory," said José Miguel Vivanco, director of the Americas division at Human Rights Watch (Human Rights Watch 2015). Following the report of the GIEI, the Inter-American Commission on Human Rights created "The Special Follow-Up Mechanism for the Ayotzinapa Case" (MESA, for its Spanish initials), which monitors compliance with Precautionary Measure 409/14 and with the recommendations that the GIEI formulated in its two reports. MESA grants the families of the forty-three missing students a central role in its efforts.

The Inter-American Commission on Human Rights (IACHR), along with the Inter-American Court of Human Rights, is one of the bodies that comprise the Inter-American system for the promotion and protection of human rights in the continent. As an independent legal organ, the commission's intervention in domestic scenarios, such as this case, always has a strong impact. Even if the results of this intervention in terms of achieving justice can be considered partial or incomplete, the authority of the commission as an independent body that imposes limits on the power of a national government challenges the prevailing structural impunity. As is clear in the case of Ayotzinapa, the transnational legal framework allows domestic actors to seek justice when the channels in their country are blocked. Even if achieving justice ultimately depends on the political will of the national government, without the intervention of transnational legal mechanisms and bodies, such as the IACHR, the demand for justice becomes even more precarious.

In terms of memory, the GIEI was the product of legal mechanisms in which a regional memory of past human rights violations is inscribed-and not only a memory of the violations but also a memory of activism, of the struggles that led to the very existence of these norms and frameworks. At the same time, and considering the involvement of the Argentine Forensic Anthropology Team (EAAF) in this case, it is also possible to identify the existence of a memory of knowledge, of procedures that were learned and then transmitted in the context of struggles against human rights violations and are then recuperated and transnationalized. Thus, beyond the strict legal framework, the intervention of the IACHR represents the circulation of transnational memories on disappearances across and beyond boundaries. The regional character of the body, far from limiting this circulation, reinforces its meaning.

\section{“The Ayotzinapa Case: A Cartography of Violence”}

A very different initiative, although connected with the previous one, is the platform "The Ayotzinapa Case: A Cartography of Violence," designed 
by Forensic Architecture in 2017. Forensic Architecture is an independent research agency based at Goldsmiths, University of London, composed of an interdisciplinary team of investigators, including architects, scholars, artists, filmmakers, software developers, investigative journalists, archaeologists, lawyers, and scientists. They often undertake collaborative investigations with partners, such as Amnesty International, Human Rights Watch, and Centro para la Acción Legal en Derechos Humanos, and work with international offices such as the UN Special Rapporteur for Counter-Terrorism and Human Rights. Forensic Architecture combines a set of innovative toolsarchitectural analysis, models, and animations - to investigate human rights violations and uncover facts denied by governments. This evidence is presented in political and legal contexts, including international courts, truth commissions, and human rights and environmental forums. The work of Forensic Architecture involves not only a redefinition of the terms "forensic" and "architecture," which shift each other's meaning when brought together, but also an innovative way of conceiving the relationship between "aesthetic" and "research" in the context of human rights activism.

In 2017, Forensic Architecture was commissioned by—and worked in collaboration with-the EAAF and Centro de Derechos Humanos Miguel Agustín Pro Juárez (Centro Prodh, one of the leading Mexican nongovernmental organizations) to create an interactive cartographic platform to map out the different narratives of the attack on the students from Ayotzinapa. The collaboration itself conveys the entanglement of national and transnational actors and the mobilization of resources from European as well as American sources. As they describe it,

The project aims to reconstruct, for the first time, the entirety of the known events that took place that night in and around Iguala, and to provide a forensic tool for researchers to further the investigation. The data on which the platform is based draws from publicly available investigations, videos, media histories, photographs and phone logs. The first and more important of our sources are two reports by a group of five experts referred to as the International Group of Independent Experts (GIEI) . . .

Thousands of pages of reports have thereafter been broken down into almost five thousand data-points, each recording a single reported incident, such as an instance of two-way communication, movements or the mishandling of evidence. These data-points have been located, timed and tagged according to the actors involved, and the type of incident they describe. Each data-point is also assigned a narrative description.

This demonstrates, in a clear graphic and cartographic form, the level of collusion and coordination between state agencies and organised crime, throughout the night... 
The project thus reveals a cartography of violence spanning from the street corner level to the entire state of Guerrero. It describes an act of violence that is no longer a singular event but a prolonged act, which persists to this day in the continued absence of the 43 students.

It also seeks to demonstrate the way in which collective civil society initiatives, undertaking independent investigations using innovative analytical tools, could help investigate complex crimes and confront criminal impunity and the failures of Mexican law enforcement.

In particular, it reaffirms our commitment to heal the open wound of the Ayotzinapa case and to work until the truth of the night is clarified, and the students' whereabouts are known. (https://www.forensic-architecture.org )

Unlike other investigations that Forensic Architecture conducted, the Ayotzinapa project did not present new evidence. Among the main sources used were the two reports published by the GIEI and the book Una historia oral de la infamia: Los ataques a los normalistas de Ayotzinapa (2016) by John Gibler, a book composed entirely of interviews conducted with survivors in the months following the disappearance. Rather than uncovering new evidence, Forensic Architecture instead honed in this project the practice of collating and presenting data in an accessible manner.

In addition to the platform, the project was exhibited as part of Forensic Architecture: Towards an Investigative Aesthetic from 9 September 2017 until 7 January 2018 at the Museo Universitario de Arte Contemporáneo (MUAC) in Mexico City.

Taking into account that this platform utilizes the reports published by the GIEI as one of its main sources, it is possible to establish both a continuation as well as significant differences. Both are investigations whose main goal is to uncover the truth. Forensic Architecture developed this platform not as a new investigation to add more or better evidence to a trial but as a way to communicate what happened that night to a global audience. Instead of using the established format of a "report," a principal way in which NGOs perform the task of "information politics" (Keck and Sikkink 1998), they developed an aesthetic object-the platform-that was exhibited in museums. Unlike the report, the interactive character of the platform engages the visitor, who also becomes a detective in a certain sense who has to discover the facts while navigating the website. The exhibition at the MUAC also encompassed immersive experiences, such as entering a dark room that reproduces the acoustic experience of a prison in Saydnaya.

"We share our work with the public via leading research and cultural institutes. Our main beneficiaries are always the victims of human rights violations, and communities in conflict zones or otherwise subject to state failure or violence," they affirm. Here, "public" appeals to a global civil soci- 
ety capable of being interpellated by the event and multiplying the efforts to achieve justice.

\section{Ayotzinapa: Visual Action}

Ayotzinapa: Visual Action was an initiative launched by the Argentine photographer Marcelo Brodsky, together with the Centro de Derechos Humanos de la Montaña Tlachinollan in November 2014. For this action, Brodsky invited people from all over the world to photograph themselves in groups with the slogan that has become a symbol for the search of the disappeared: "Vivos se los llevaron, vivos los queremos" (They took them alive, we want them alive). The initiative was aimed to create a transnational campaign that could help provide legitimacy to the cause through the expression of solidarity with the local activists. The relevance of Ayotzinapa: Visual Action is that, beyond constituting an enactment of two modes of practices of the work of global justice- - bearing witness and solidarity - it draws upon transnational memories on disappearance, particularly from Argentina, to reframe the meaning of the event.

Due to a strong response to the initiative, Visual Action became an exhibition composed of hundreds of photos from all over the world. While the primary space of exhibition was the web, I analyze here a book publication that gathers a selection of the pictures from the action, as well as a compilation of other photos, short texts, and essays related to the case. The first part of the book-the Action-is composed of fifty-two photos. All of them follow a similar pattern with slight variations. The pictures depict an assemblage of people standing or sitting in rows, facing the camera directly.

The participants are holding up banners. These are either letters placed together to show the complete message or single banners in which the manifestation chant is fully included. Along with the most important slogan, "They took them alive, we want them alive," one can find "Justice for Ayotzinapa," "We are all Ayotzinapa," "No podemos ni queremos olvidar," "We can't and don't want to forget," mostly in Spanish. The settings also vary: some are taken outdoors, in scenarios that can be easily recognizable, such as Nueva Delhi in India or La Boca in Buenos Aires, while others are framed in spaces such as the European Center for Constitutional Rights in Berlin or the University of New Brunswick in Canada.

The photos perform a transnational community of belonging composed by anonymous individuals that can nevertheless unite in a new transnational space created by the photos themselves. The more remote the place depicted, the stronger the idea that Ayotzinapa is a cause with such an importance that it received the attention of communities far away, for example from Bangladesh. 
Despite their differences, the photos are identical in the message that each and all of the people convey and the solidarity with the cause of Ayotzinapa, which is inscribed in the slogans, the photos of the disappeared students, or in the use of the term "Ayotzinapa" itself. But solidarity —even if it is the most conventional meaning and therefore the most explicit-is neither the exclusive nor the main meaning that these carefully staged photos aim to transmit. Read as a whole, the initiative aims to contest the Mexican structures of impunity by framing the disappearances of the students of Ayotzinapa as an "enforced disappearance," and thus as a human rights violation perpetrated by the state.

To do so, the initiative operates by reframing the issue. Keck and Sikkink stress that building cognitive frames is an essential component of networks' political strategies. If the new framework succeeds, it will influence broader public understanding, which is called frame resonance (Keck and Sikkink 2011: 28-29).

For reframing the issue, the exhibition removes the disappearance of the forty-three students from the frame of the War on Drugs - where the boundaries between victims and perpetrators are blurred and the responsibility of the state as perpetrator is not clear-and inscribes it in the long history of enforced disappearances experienced by Latin America in the 1970s and 1980s, linking it particularly with Argentina. It does so by mobilizing the repertoire of the Argentine visual legacy and applying it in order to give meaning to the event in Mexico. Visual Action thus closely links both contextsArgentina and Mexico — so that they become, in certain sense, identical.

The first photo we see in Visual Action is not one of the group pictures showing transnational solidarity with Ayotzinapa but the picture Buena Memoria (Good Memory), a well-known work of Marcelo Brodsky. Brodsky, who launched the initiative, is an Argentine visual artist known for his exhibitions and essays on memory. These include works such as Nexus, Tree Time, Visual Correspondences, or 1968: The Fire of Ideas.

Buena Memoria is a visual essay that deals with the collective memory of the years under the Argentine dictatorship. It consists of a class picture of 1967 of the Colegio Nacional de Buenos Aires, the artist's own class picture. In their essay on the work, Marianne Hirsch and Leo Spitzer describe it as follows:

The depicted children are lined up in four rows facing forward and smiling; some are looking off to the side...

In the installation, the picture is intact but blown up to huge proportions (Brodsky labels it a "gigantograph"). But each of the children's bodies is inscribed with a brief text written on the photo that connects the past to the present, some faces are circled and others are circled and crossed out. The text is simple, abbreviated: "Silvia is very tall as always. She is a physical therapist;" 


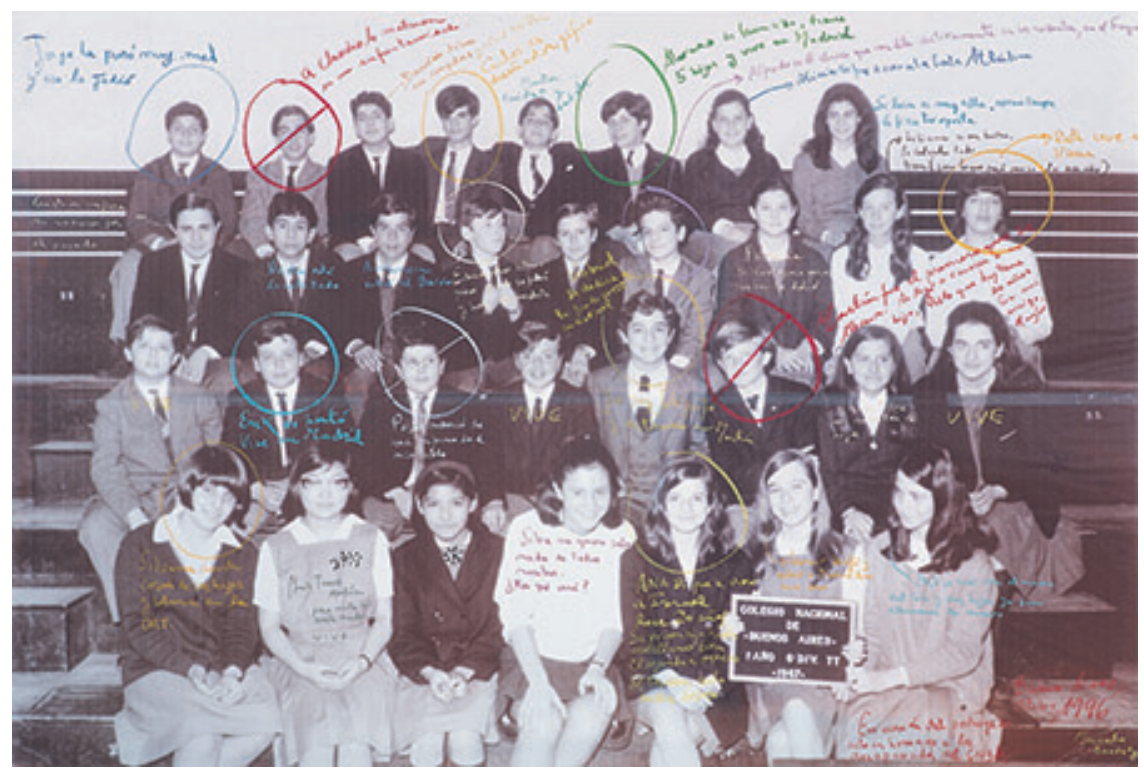

Figure 2.1. La Clase. (C) Marcelo Brodsky, 1996.

"Carlos is a graphic designer;" "Claudio was killed fighting the military in December 1975.”

In "Buena Memoria" the violent mark of erasure on the skin-like surface of the photographic print recalls the violence of selecting individuals out of the social body with the intention of annihilating them and their memory. The lines etched into the surface of the print transmit that violence, puncturing us as viewers. (Hirsch and Spitzer 2014: 270)

The second photograph we see in Visual Action is also a class picture of the Colegio Nacional de Buenos Aires. Instead of being a testimony of the past, this photo features the present. We see a class picture of 2014, in which young students of the Buenos Aires school are facing the camera holding up individual signs that together form the slogan "They took them alive, we want them alive/ Ayotzinapa," along with flags of Argentina and Mexico. The image serves as a bridge between past and present, as well as between the two countries. These students are aware of the fate of the disappeared students of the Colegio Nacional - the students recorded in the photo of 1967 were once sitting in that same classroom, playing in the same corridors-and it is precisely out of this memory of state terrorism, violence, and loss that they act in solidarity with the students suffering the same fate in the pres- 
ent-those of Ayotzinapa. Almost everyone looks solemn, serious, largely hopeless. Although appropriate for the occasion, this somber look contrasts with the expected cheerfulness typical of youth. In this regard, the prevailing atmosphere of the photo of Buena Memoria from 1967 diverges remarkably from that of 2014. The dissonance between the grief and sorrow of the facial expressions and the qualities of youth exposes the vulnerability of the group. They are young, they have a life to enjoy, they are innocent, but life reveals itself to be precarious, as it can be suddenly snatched away by the state. The viewer is confronted with the imminence of a violence that the students of the Colegio Nacional could, but fortunately did not, suffer. Moreover, what they testify to is the very absence of those lives that have been taken. In demanding the reappearance of the missing students from Ayotzinapa, they represent the image that is not included in the series, the photograph of the students alive. An impossible object- the disappeared picture, the picture of the disappeared-becomes the punctum of the project, an archival document of the erasure by violence. The exhibition thus conflates two temporalities: the meaning it aims to transmit is that what happened to the students of the Colegio Nacional de Buenos Aires in 1967 has happened again in Mexico, but with more cruelty. While in the initial photo two faces have been crossed out, in the missing picture we would see forty-three faces erased.

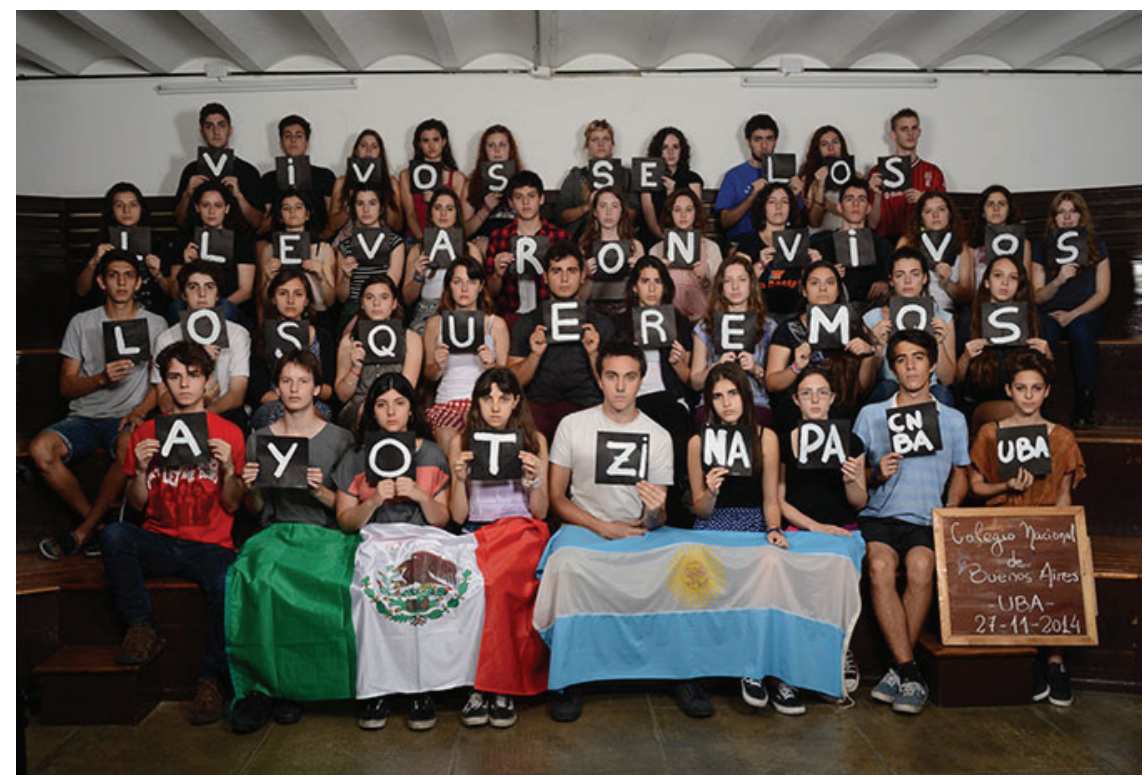

Figure 2.2. Vivos. (C) Marcelo Brodsky, Colegio Nacional de Bs. As., 2014. 


\section{Conclusion}

The initiatives analyzed, though merely brief examples of the multiple ways in which global civil society became involved in the Ayotzinapa case, show the convergence of different strategies, as well as the common values underpinning the work of global justice. Did these initiatives work? Did they help to bring about a significant change? The answer depends on how we measure their impact. On the one hand, Ayotzinapa definitively opened up the debate on enforced disappearance in the country. Highlighting that Ayotzinapa was not an isolated case but an example of the complex situation of disappearances in the framework of the War on Drugs helped to bring visibility and meaning to the phenomenon. Groups of relatives of disappeared that existed from the period of the Dirty War and newly formed groups of relatives from the War on Drugs united in a new umbrella group called Movimiento por Nuestros Desaparecidos in order to struggle against disappearance in the political, social, and legislative dimensions. The Movimiento demanded a specific legal framework to address disappearances, and a new law was in fact approved in 2017. The Ley General en Materia de Desaparición Forzada de Personas, Desaparición Cometida por Particulares y del Sistema Nacional de Búsqueda de Personas adapts the international framework on enforced disappearance to the particularities of the Mexican context.

Even though some of these collectives and organizations existed before, Ayotzinapa helped them to articulate their demands in the framework of a unified a movement, which strengthened them. Many publications, documentaries, and films that discuss the history of disappearances tell the story of the current situation of violence in the country and recover a memory of human rights violations. From this perspective, the work of a transnational advocacy network that amplified the phenomenon not only made it visible and provided it with meaning but also helped to achieve concrete outcomes, such as the new law and measures to fight against enforced disappearance in the complex Mexican scenario.

Nevertheless, a more skeptical perspective is also possible. After all the activism that took-and still takes-place around Ayotzinapa, the case remains unsolved, and the whereabouts of the students have not been determined. Justice has not been achieved. At a general level, violence in Mexico has not decreased since 2014. The last years have registered the highest numbers of dead and disappeared people since 2006. For many activists who appeared hopeful about the possibility of change, Ayotzinapa meant a disillusion (Velez 2017).

Therefore, a categorical answer to the question "Does transnational civil society bring about change in struggling against human rights violations?" is not possible. If we measure the results in terms of radical change, the answer 
is probably no. But, if we consider, as Kurasawa or Sikkink suggest, that the results to be expected are always incomplete, contingent, and limited, and that the work of global justice has a Sisyphean character with no moment of transcendence, the answer changes to a more optimistic position. The Ayotzinapa case shows that even if partial or incomplete, the transnational work of memory has provided a frame and established new resources to continue the struggle.

\section{Acknowledgments}

This research has received funding from the European Research Council (ERC) under the European Union's Horizon 2020 research and innovation program ("Digital Memories," Grant agreement n 677955).

Silvana Mandolessi is professor of cultural studies at KU Leuven. She is the author of Digital Reason: A Guide to Meaning, Medium, Community in a Modern World (with Jan Baetens and Ortwin de Graef) (2020) and coeditor of El pasado inasequible: Desaparecidos, hijos y combatientes en el arte y la literatura del nuevo milenio (2018), Estudios sobre memoria: Perspectivas actuales $y$ nuevos escenarios (2015), and Transnational Memory in the Hispanic World (2014). She is currently director of the ERC project "We Are All Ayotzinapa: The Role of Digital Media in the Shaping of Transnational Memories on Disappearance."

\section{References}

Anaya Muñoz, Alejandro. 2013. "Non-state Actors as Violators in Mexico: A Hard Case for Global Human Rights Norms." In The Politics of the Globalization of Law: Getting from Rights to Justice, edited by Alison Brysk, 180-98. New York: Routledge.

Assmann, Aleida. 2014. "Transnational Memories." European Review 22 (4): 546-556.

Assmann, Aleida, and Sebastian Conrad, eds. 2010. Memory in a Global Age: Discourses, Practices and Trajectories. Basingstoke: Palgrave Macmillan.

Bleiker, Roland. 2004. Popular Dissent, Human Agency and Global Politics. Cambridge: Cambridge University Press.

Bond, Lucy, and Jessica Rapson, eds. 2014. The Transcultural Turn: Interrogating Memory Between and Beyond Borders. Berlin: De Gruyter.

Bond, Lucy, Stef Craps, and Peter Vermeulen, eds. 2017. Memory Unbound: Tracing the Dynamics of Memory Studies. New York: Berghahn Books.

Brodsky, Marcelo, ed. 2015. Ayotzinapa: Acción Visual. Santiago de Chile: Museo de la Memoria y los Derechos Humanos. 
Chandler, David. 2004. Constructing Global Civil Society: Morality and Power in International Relations. Basingstoke: Palgrave Macmillan.

De Cesari, Chiara, and Ann Rigney, eds. 2014. Transnational Memory: Circulation, Articulation, Scales. Berlin: De Gruyter.

De Greiff, Pablo, and Ciaran Cronin, eds. 2002. Global Justice and Transnational Politics: Essays on the Moral and Political Challenges of Globalization. Cambridge, MA: MIT Press.

Dutrénit Bielous, Silvia, and Gonzalo Varela Petito. 2010. Tramitando el pasado: Violaciones de los derechos humanos y agendas gubernamentales en casos latinoamericanos. México: Flacso México.

Edwards, Michael, ed. 2011. The Oxford Handbook of Civil Society. Oxford: Oxford University Press.

Erll, Astrid. 2011. “Travelling Memory." Parallax 17(4): 4-18.

Erll, Astrid, and Ann Rigney. 2018. "Editorial." In "Cultural Memory Studies after the Transnational Turn," special issue, Memory Studies 11(3): 272-73.

Forensic Architecture. 2017. "Ayotzinapa: una cartografía de la violencia." Retrieved 17 March 2020 from http://www.plataforma-ayotzinapa.org/.

Garde-Hansen, Joanne, Andrew Hoskins, and Anna Reading, eds. 2009. Save as . . Digital Memories. Basingstoke: Palgrave Macmillan.

Groes, Sebastian, ed. 2016. Memory in the Twenty-First Century: New Critical Perspectives from the Arts, Humanities, and Sciences. Basingstoke: Palgrave Macmillan.

Grupo Interdisciplinario de Expertos Independientes. 2015. Informe Ayotzinapa: Investigación y primeras conclusiones de las desapariciones y homicidios de los normalistas de Ayotzinapa. México: Grupo Interdisciplinario de Expertos Independientes.

- 2016. Informe Aytozinapa II: Avances y nuevas conclusiones sobre la investigación, búsqueda $y$ atención a las víctimas. México: Grupo Interdisciplinario de Expertos Independientes.

Hays, Sharon. 1994. "Structure and Agency and the Sticky Problem of Culture." Sociological Theory 12(1): 57-72.

Hirsch, Marianne, and Leo Spitzer. 2014. "School Photos and their Afterlives." In Feeling Photography, edited by Elspeth Brown and Thy Phu, 252-273. Durham: Duke University Press.

Hoskins, Andrew. 2018. "Memory of the Multitude: The End of Collective Memory." In Digital Memory Studies: Media Pasts in Transition, edited by Andrew Hoskins, 85-109. New York: Routledge. Kindle.

Human Rights Watch. 2015. "Mexico: Damning Report on Disappearances," September 6. Retrieved 16 March 2020 from https://www.hrw.org/news/2015/09/06/ mexico-damning-report-disappearances.

Inglis, David. 2016. "Globalization and/of Memory: On the Complexification and Contestation of Memory Cultures and Practices." In Routledge International Handbook of Memory Studies, edited by Anna Lisa Tota and Trever Hagen, 143-57. London: Routledge.

Jelin, Elizabeth. 2017. La lucha por el pasado: Cómo construimos la memoria social. Buenos Aires: Siglo XXI.

Jordan, Lisa. 2011. "Global Civil Society." In The Oxford Handbook of Civil Society, edited by Michael Edwards, 93-105. Oxford: Oxford University Press.

Karl, Sylvia. 2014. "Missing in Mexico: Denied Victims, Neglected Stories." Culture \& History Digital Journal 3(2): 1-17.

Keck, Margaret E., and Kathryn Sikkink. 1998. Activists beyond Borders: Advocacy Networks in International Politics. Ithaca, NY: Cornell University Press.

Keck, Margaret E., and Kathryn Sikkink. 2011. "Transnational Advocacy Networks in the Movement Society." In Global Activism Reader, edited by Luc Reydams, 24-34. New York: Continuum.

This chapter of "Agency in Transnational Memory Politics" edited by Jenny Wüstenberg and Aline Sierp is made available open access under a CC BY-NC-ND 4.0 license, thanks to the support of the European Research Council (ERC) under the European Union's Horizon 2020 research and innovation program (“Digital Memories," Grant agreement $n^{\circ} 677955$ ). Not for resale. 
Kurasawa, Fuyuki. 2007. The Work of Global Justice: Human Rights as Practices. Cambridge: Cambridge University Press.

Neiger, Motti, Oren Meyers, and Eyal Zandberg, eds. 2011. On Media Memory: Collective Memory in a New Media Age. Basingstoke: Palgrave Macmillan.

Levy, Daniel, and Natan Sznaider. 2006. The Holocaust and Memory in the Global Age. Translated by Assenka Oksiloff. Philadelphia: Temple University Press.

Reading, Anna. 2011. "Memory and Digital Media: Six Dynamics of the Globital Memory Field." In On Media Memory: Collective Memory in a New Media Age, edited by Motti Neiger, Oren Meyers, and Eyal Zandberg, 241-252. Basingstoke: Palgrave Macmillan.

Rigney, Ann. 2016. "Cultural Memory Studies: Mediation, Narrative, and the Aesthetic." In Routledge International Handbook of Memory Studies, edited by Anna Lisa Tota and Trever Hagen, 65-76. London: Routledge.

Rothberg, Michael. 2009. Multidirectional Memory: Remembering the Holocaust in the Age of Decolonization. Stanford, CA: Stanford University Press.

Sierp, Aline, and Jenny Wüstenberg. 2015. "Linking the Local and the Transnational: Rethinking Memory Politics in Europe." Journal of Contemporary European Studies 23(3): 321-329.

Sikkink, Kathryn. 2017. Evidence for Hope: Making Human Rights Work in the 21st Century. Princeton: Princeton University Press.

Vélez, Alejandro. 2017. "México, entre ilusiones transicionales y violencias inasibles." In La ilusión de la justicia transicional: Perspectivas criticas desde el sur global, edited by Alejandro Castillejo Cuéllar, 431-453. Bogotá: Universidad de los Andes. 